\title{
Watershed Prioritization using Morphometric and Land Use/Land Cover Parameters of Dudhganga Catchment Kashmir Valley India using Spatial Technology
}

Mohd Iqbal* and Haroon Sajjad

Department of Geography, Faculty of Natural Sciences, Jamia Millialslamia, New Delhi- 110025, India

\begin{abstract}
Watershed prioritization has gained importance in natural resources management, especially in the context of watershed management. Morphometric and land use analysis has been commonly applied to prioritization of watersheds. In the present study, prioritization on the basis of morphometricand land use analysis of watersheds have been performed for the Dudhganga catchment of Kashmir Valley J\&K. Various morphometric parameters, namely linear and shape have been determined for each watersheds and assigned ranks on the basis of value/relationship so as to arrive at a compound value for a final ranking of the watershed. Land use/land cover change analysis of the watersheds has been carried out using multi-temporal data of Land sat TM of 1991 and Land sat TM of 2010. The study demonstrates the significant land use changes especially in built up land, agricultural lands, plantation, forest, scrubland, and wastelands from 1991 to 2010. Based on morphometric and land use/land cover analysis, the watersheds have been classified into three categories as high, medium and low in terms of priority for conservation and management of natural resources.
\end{abstract}

Keywords: Prioritization; Land use/Land cover; Morphometric; Dudhganga; Catchment

\section{Introduction}

Morphometry is the measurement and mathematical analysis of the configuration of the earth's surface, shape and dimension of its landforms [1-4]. A major emphasis in geomorphology over the past several decades has been on the development of quantitative physiographic methods to describe the evolution and behaviour of surface drainage networks [5-7]. Most previous morphometric analyses were based on arbitrary areas or individual channel segments. Using watershed as a basic unit in morphometric analysis is the most logical choice. A watershed is the surface area drained by a part or the totality of one or several given water courses and can be taken as a basic erosional landscape element where land and water resources interact in a perceptible manner. In fact, they are the fundamental units of the fluvial landscape and a great amount of research has focused on their geometric characteristics, including the topology of the stream networks and quantitative description of drainage texture, pattern and shape [7]. The morphometric characteristics at the watershed scale may contain important information regarding its formation and development because all hydrologic and geomorphic processes occur within the watershed [8].

The quantitative analysis of morphometric parameters is found to be of immense utility in river basin evaluation, watershed prioritization for soil and water conservation and natural resources management at watershed level. Morphometric analysis of a watershed provides a quantitative description of the drainage system which is an important aspect of the characterization of watersheds [9]. The influence of drainage morphometry is very significant in understanding the landform processes, soil physical properties and erosional characteristics. Drainage characteristics of many river basins and sub basins in different parts of the globe have been studied using conventional methods $[5,10,11]$. Geographical Information System (GIS) techniques are now a day used for assessing various terrain and morphometric parameters of the drainage basins and watersheds, as they provide a flexible environment and a powerful tool for the manipulation and analysis of spatial information.
Land use and land cover (LULC) change is a major issue of global environment change. Land use/land cover mapping is essential component wherein other parameters are integrated on the requirement basis to drive various developmental index for land and water resource. Land cover is defined as the biophysical state of Earth's surface and immediate subsurface. The term refers to the type of vegetation that covers the land surface, other aspects of the physical environment, such as soils, biodiversity as well as human structures, such as buildings or pavement. Land use, involves both the manner in which the biophysical attributes of the land are manipulated and the intent underlying that manipulation-the purpose for which land is used [12]. Anthropogenic altercations of the natural landscape by means of urbanization, agriculture and forestry have been a continuous and increasing process for millennia. Regions of natural vegetation and land cover are removed and replaced with numerous human-managed systems of altered structure. The resulting land use and land cover patterns are composed of both the natural and humandeveloped environments. Studies have shown that there remain only few landscapes on the earth those are still in their natural state. Due to anthropogenic activities, the earth surface is being significantly altered in some manner or the other and man's presence on the earth and his use of land has had a profound effect upon the natural environment thus resulting into an observable pattern in the land use/land cover over time. In this research an attempt has been made to assess the land

*Corresponding author: Mohdlqbal Bhat, Department of Geography, Faculty of Natural Sciences, JamiaMillialslamia, New Delhi- 110025, India, Tel: 9018348875 E-mail: iqbalbhat901@gmail.com

Received December 16, 2013; Accepted January 30, 2014; Published February 05, 2014

Citation: Iqbal M, Sajjad H (2014) Watershed Prioritization using Morphometric and Land Use/Land Cover Parameters of Dudhganga Catchment Kashmir Valley India using Spatial Technology. J Geophys Remote Sensing 3: 115. doi:10.4172/21690049.1000115

Copyright: (c) 2014 lqbal M, et al. This is an open-access article distributed under the terms of the Creative Commons Attribution License, which permits unrestricted use, distribution, and reproduction in any medium, provided the original author and source are credited. 
use/land cover dynamics and prioritize the watersheds on the basis of changes in land use categories of Dudhganga catchment.

The resource development programs are applied generally on watershed basis and thus prioritization is essential for proper planning and management of the natural resources for sustainable development [13]. Drainage basins, catchments and sub catchments are the fundamental units of the management of the land and water, identified as planning units for administrative purposes to conserve natural resources $[14,15]$. Thus the integrated approach plays an important role for sustainable development and management of natural resources. Watershed prioritization is the ranking of different watersheds of a catchment according to the order in which they have to be taken for treatment and soil conservation measures. Morphometric analysis and land use parameters could be used for prioritization of watersheds by studying different linear and aerial parameters of the watershed even without the availability of soil maps. However, while considering watershed conservation work, it is not feasible to take the whole area at once. Thus the whole catchment is divided into several smaller units, as watersheds D1A, D1B, D1C, D2A, and D2B, according to All India Land Use Survey [16], by considering its drainage system. In the present study integration of the morphometric and the land use/ land cover analysis has been carried out at the watershed level using modern geospatial tools which could be the vital importance for the conservation and management strategies of Dudhganga catchment Kashmir Valley.

\section{Study Area}

Dudhganga catchment of Kashmir Valley (Figure 1), located in the northern part of India between $33^{\circ} 42^{\prime}$ to $34^{\circ} 50^{\prime} \mathrm{N}$ and $74^{\circ} 24^{\prime}$ to $74^{\circ} 54^{\prime}$ E, covers an area of $660 \mathrm{~km}^{2}$. The area supports a varied topography exhibiting altitudinal extremes of 1557 to $4663 \mathrm{~m}$ above mean sea level. The area consists of the lofty Pir-Panjal and flat-topped karewas as foothills and plains. The Pir-Panjal mountain range covers the Kashmir Valley on the south and southwest, separating it from the Chenab valley and the Jammu region. The karewa formation is a unique physiographic feature of this area. These are lacustrine deposits of the Pleistocene age composed of clays, sands, and silts. The soils in the area are generally of three types, viz., loamy soil, karewa soil and poorly developed mountain soil [17]. Climate of the area is temperate type with warm summers and cold winters. The mean annual temperature is $20^{\circ} \mathrm{C}$. Average annual rainfall in the area is $669 \mathrm{~mm}$ and maximum precipitation occurs during March to April when westerly winds strike the northern face of the Pir-Panjal Mountains. The geology of the area is quite diverse ranging from Archean to Recent; Pir-Panjal represents rocks of a wide range in age. The commonest of the rocks present in the area are Panjal traps, karewa and alluvium. Drainage of the area is quite significant as most of the drainage flows into river Jhelum. Dudhganga is the important tributaries of river Jhelum which originates near Tatakuti Mountain. (Figure 1)

\section{Methodology}

Morphometric analysis of a drainage system requires delineation of all existing streams. The stream delineation was done digitally in GIS (Arc view 3.2a) system. All tributaries of different extents and patterns were digitized from survey of India to posheets 1961 (1:50,000 scale) and the catchment boundary was also determined for Dudhganga catchment. Similarly, five watersheds (D1A, D1B, D1C, D2A and D2B) were also delineated and measured for intensive study. Digitization work was carried out for entire analysis of drainage morphometry. The different morphometric parameters have been determined as shown in
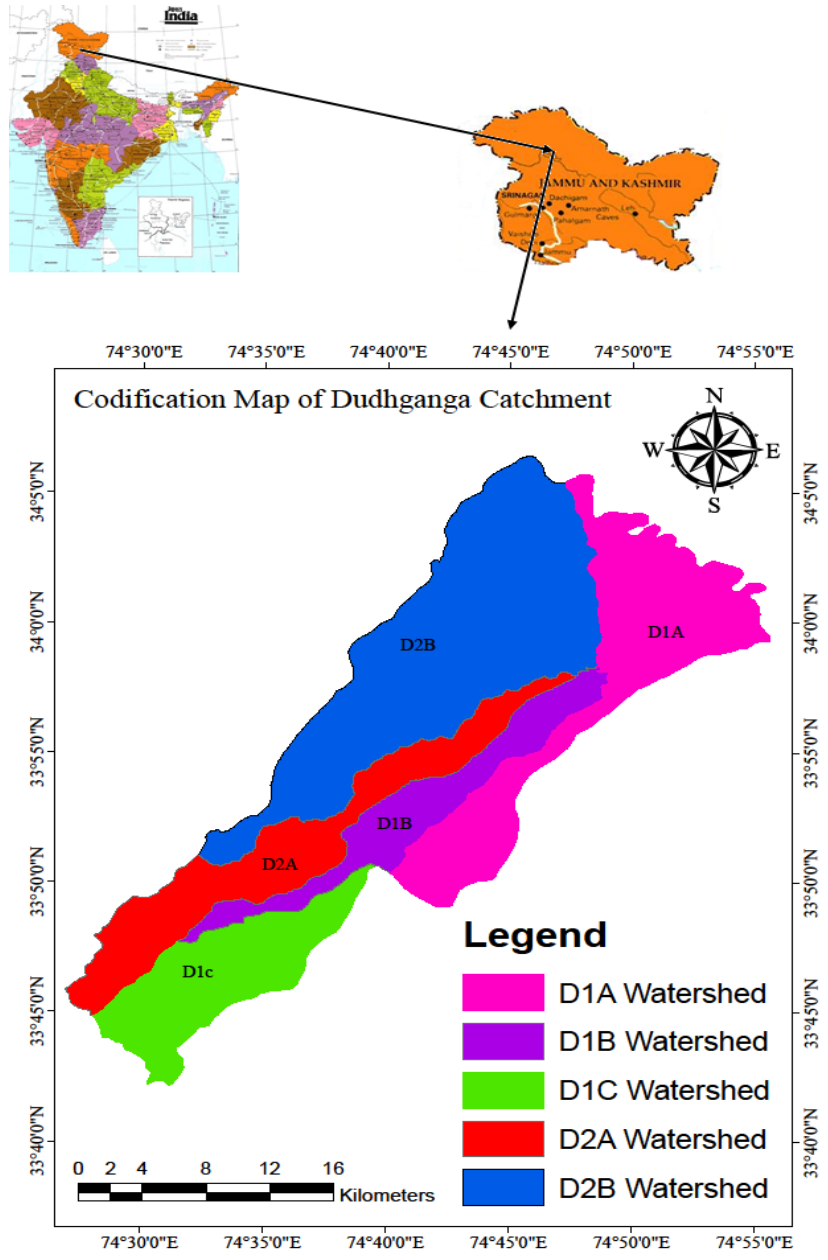

Figure 1: Geographical location of Dudhganga Catchment, Kashmir Valley, India.

Table1. The study involved detecting changes in the LULC for which, multi-date satellite images were used that included two sets of LandsatThematic Mapper images dated 15 October 1991 and 31 October 2010. Image-to-image registration of the two selected images was carried out with the help of base map coordinates. The linear contrast stretching and band-to band ratioing enhancement were applied to the images for increasing the interpretability. The digital image classification helped in identifying, delineating and mapping of the land use/land cover into a number of classes. The image classification was performed using the maximum likelihood classifier decision rule of the supervised classification method. The overall accuracy was determined as 86 per cent. Land use/land cover changes were determined using the post classification change detection method and the land use/land cover statistics derived from data sets were computed and compared for quantification of change.

\section{Results and Discussion}

Drainage pattern is characterized by irregular branching of tributaries in many directions with an angle less than $90^{\circ}$. The Catchment is divided into five watersheds with codes D1A, D1B, D1C, $\mathrm{D} 2 \mathrm{~A}$, and D2B. 
Citation: Iqbal M, Sajjad H (2014) Watershed Prioritization using Morphometric and Land Use/Land Cover Parameters of Dudhganga Catchment Kashmir Valley India using Spatial Technology. J Geophys Remote Sensing 3: 115. doi:10.4172/2169-0049.1000115

Page 3 of 12

\begin{tabular}{|c|c|c|}
\hline $\begin{array}{l}\text { Morphometric } \\
\text { Parameters }\end{array}$ & Formula & Reference \\
\hline Stream order & Hierarchical rank & Strahler [9] \\
\hline $\begin{array}{l}\text { Stream length } \\
(\mathrm{Lu})\end{array}$ & Length of the stream & Horton [5] \\
\hline $\begin{array}{l}\text { Bifurcation ratio } \\
\qquad(\mathrm{Rb})\end{array}$ & $\begin{array}{l}\qquad \mathrm{Rb}=\mathrm{Nu} / \mathrm{Nu}+1 \\
\text { where } \mathrm{Nu}=\text { Total no. of stream segments of order ' } u \text { ' } \\
\mathrm{Nu}+1=\text { Number of segments of the next higher order }\end{array}$ & Schumn [21] \\
\hline $\begin{array}{l}\text { Drainage density } \\
\text { (Dd) }\end{array}$ & $\begin{array}{c}\mathrm{Dd}=\mathrm{Lu} / \mathrm{A} \\
\text { where } \mathrm{Dd}=\mathrm{drainage} \text { density } \\
\text { Lu=total stream length of all orders } \\
A=\text { area of the basin }\left(\mathrm{km}^{2}\right)\end{array}$ & Horton [5] \\
\hline $\begin{array}{l}\text { Stream frequency } \\
\text { (Fs) }\end{array}$ & $\begin{array}{c}\mathrm{Fs}=\mathrm{Nu} / \mathrm{A} \\
\text { where Fs=stream frequency } \\
\mathrm{Nu}=\text { total number of streams of streams of all orders } \\
\mathrm{A}=\text { area of the basin, } \mathrm{km}^{2}\end{array}$ & Horton [5] \\
\hline $\begin{array}{l}\text { Circulatory ratio } \\
\text { (Rc) }\end{array}$ & $\begin{array}{c}\mathrm{Rc}=4{ }^{*} \Pi{ }^{*} \mathrm{~A} / \mathrm{P}^{2} \\
\text { where } \mathrm{Rc}=\text { circularity ratio } \\
\Pi=\pi \text { value i.e., } 3.141 \\
\mathrm{~A}=\text { area of the basin, } \mathrm{km}{ }^{2} \\
\mathrm{P}^{2}=\text { square of the perimeter, } \mathrm{km}\end{array}$ & Miller [24] \\
\hline $\begin{array}{l}\text { Elongation ratio } \\
\qquad(\mathrm{Re})\end{array}$ & $\begin{array}{c}\mathrm{Re}=2 \sqrt{\mathrm{A}} / \pi / \mathrm{Lb} \\
\text { where } \mathrm{Re}=\text { elongation ratio } \\
\mathrm{A}=\text { area of the basin, } \mathrm{km}^{2} \\
\pi=\pi \text { value i.e., } 3.141 \\
\mathrm{Lb}=\text { basin length }\end{array}$ & Miller [24] \\
\hline $\begin{array}{l}\text { Form factor } \\
\text { (Ff) }\end{array}$ & $\begin{array}{c}\mathrm{Ff}=\mathrm{A} / \mathrm{Lb}^{2} \\
\text { where, } \mathrm{Ff}=\text { form factor } \\
\mathrm{A}=\text { area of the basin, } \mathrm{km}^{2} \\
\mathrm{Lb}=\text { basin length }\end{array}$ & Schumn [21] \\
\hline $\begin{array}{l}\text { Drainage texture } \\
(\mathrm{T})\end{array}$ & $\begin{array}{c}\mathrm{T}=\mathrm{Nu} / \mathrm{P} \\
\text { where } \mathrm{Nu}=\text { total no. of streams of all orders } \\
\mathrm{P}=\text { basin perimeter, } \mathrm{km}\end{array}$ & Horton [5] \\
\hline $\begin{array}{l}\text { Compactness coefficient } \\
\text { (Cc) }\end{array}$ & $\begin{array}{c}C c=0.2821 \mathrm{P} / \mathrm{A} 0.5 \\
\text { where } \mathrm{C}=\text { Compactness coefficient } \\
\mathrm{A}=\text { Area of the basin, } \mathrm{km}^{2} \\
\mathrm{P}=\text { basin perimeter, } \mathrm{km}\end{array}$ & Horton [5] \\
\hline
\end{tabular}

Table 1: Formulae for computation of morphometric parameters.

\begin{tabular}{|c|c|c|c|c|c|c|c|c|c|c|c|c|c|}
\hline \multirow[t]{2}{*}{ Watersheds } & \multicolumn{6}{|c|}{ Stream number in different orders } & \multirow[t]{2}{*}{$\begin{array}{c}\text { Total number } \\
\text { of streams }\end{array}$} & \multicolumn{6}{|c|}{$\begin{array}{c}\begin{array}{c}\text { Percentage of streams by different stream orders to total number of } \\
\text { streams. }\end{array}\end{array}$} \\
\hline & $1^{\text {th }}$ & $2^{\text {nd }}$ & $3^{\text {rd }}$ & $4^{\text {th }}$ & $5^{\text {th }}$ & $6^{\text {th }}$ & & $1^{\text {th }}$ & $2^{\text {nd }}$ & $3 \mathrm{rd}$ & $4^{\text {th }}$ & $5^{\text {th }}$ & $6^{\text {th }}$ \\
\hline D1A & 156 & 19 & 4 & 1 & - & 1 & 181 & 86.18 & 10.49 & 2.20 & 0.55 & - & 0.55 \\
\hline D1B & 134 & 24 & 4 & 2 & 1 & - & 165 & 81.21 & 14.54 & 2.42 & 1.21 & 0.60 & - \\
\hline D1C & 242 & 44 & 11 & 3 & 1 & - & 301 & 78.06 & 14.61 & 3.65 & 0.99 & 0.33 & - \\
\hline D2A & 278 & 57 & 12 & 2 & 1 & - & 350 & 79.42 & 16.28 & 3.42 & 0.57 & 0.28 & - \\
\hline D2B & 56 & 16 & 6 & 2 & 1 & - & 81 & 69.13 & 19.75 & 7.40 & 2.46 & 1.23 & - \\
\hline $\begin{array}{l}\text { Dudhganga } \\
\text { Catchment }\end{array}$ & 866 & 160 & 37 & 8 & 2 & 1 & 1074 & 80.63 & 14.89 & 3.44 & 0.74 & 0.18 & 0.09 \\
\hline
\end{tabular}

Table 2: Stream analysis.

\begin{tabular}{|c|c|c|c|c|c|c|c|c|c|c|c|c|c|}
\hline \multirow[t]{2}{*}{ Watersheds } & \multicolumn{6}{|c|}{ Stream number in different orders } & \multirow[t]{2}{*}{$\begin{array}{l}\text { Total number } \\
\text { of streams }\end{array}$} & \multicolumn{6}{|c|}{$\begin{array}{c}\begin{array}{c}\text { Percentage of streams by different stream orders to total number of } \\
\text { streams. }\end{array}\end{array}$} \\
\hline & $1^{\text {th }}$ & $2^{\text {nd }}$ & $3^{\text {rd }}$ & $4^{\text {th }}$ & $5^{\text {th }}$ & $6^{\text {th }}$ & & $1^{\text {th }}$ & $2^{\text {nd }}$ & 3rd & $4^{\text {th }}$ & $5^{\text {th }}$ & $6^{\text {th }}$ \\
\hline D1A & 85.66 & 19.51 & 14.66 & 12.77 & - & 17.07 & 149.67 & 57.25 & 13.03 & 9.79 & 8.53 & - & 11.40 \\
\hline D1B & 79.57 & 24.06 & 16.39 & 1.27 & 26.53 & - & 147.82 & 53.82 & 16.27 & 11.08 & 0.85 & 17.94 & - \\
\hline D1C & 160.05 & 39.31 & 18.69 & 15.76 & 10.10 & - & 243.91 & 65.61 & 16.11 & 7.66 & 6.46 & 4.14 & - \\
\hline D2A & 170.93 & 51.92 & 23.29 & 14.24 & 9.63 & - & 270.01 & 63.30 & 19.22 & 8.62 & 5.27 & 3.56 & - \\
\hline D2B & 32.40 & 6.35 & 3.94 & 2.26 & 15.88 & - & 60.83 & 53.26 & 10.43 & 6.47 & 3.71 & 26.10 & - \\
\hline $\begin{array}{l}\text { Dudhganga } \\
\text { Catchment }\end{array}$ & 528.61 & 141.15 & 76.97 & 46.3 & 62.14 & 17.07 & 872.24 & 60.60 & 16.18 & 8.82 & 5.30 & 7.12 & 1.95 \\
\hline
\end{tabular}

Table 3: Order wise total stream length.

\section{Linear aspects of Dudhgangariver}

Stream order $(\mathbf{U})$ : The designation of stream order is the first step in morphometric analysis of a drainage basin, based on the hierarchic making of streams proposed by Strahler [9]. It is defined as a measure of the position of a stream in the hierarchy of tributaries. There are 1074 streams linked with 6th order of streams sprawled over an area of $660 \mathrm{~km}^{2}$. A perusal of Table 2 indicates that the DudhgangaRiver which is the trunk stream in Dudhganga catchment is of the Sixth 


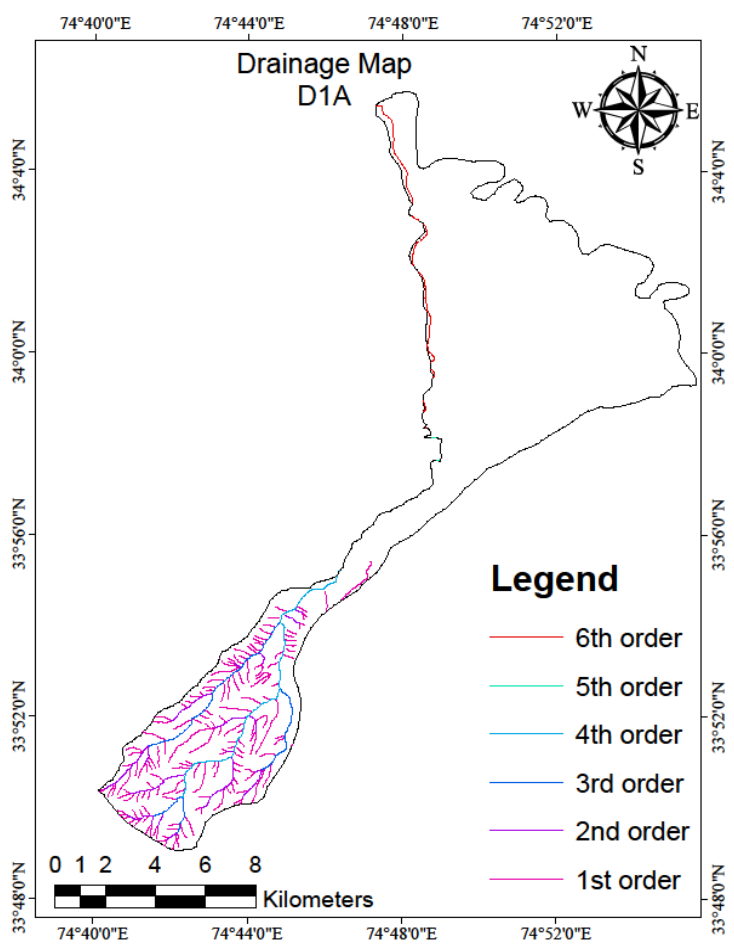

Figure 2: Drainage maps of watersheds of Dudhganga.

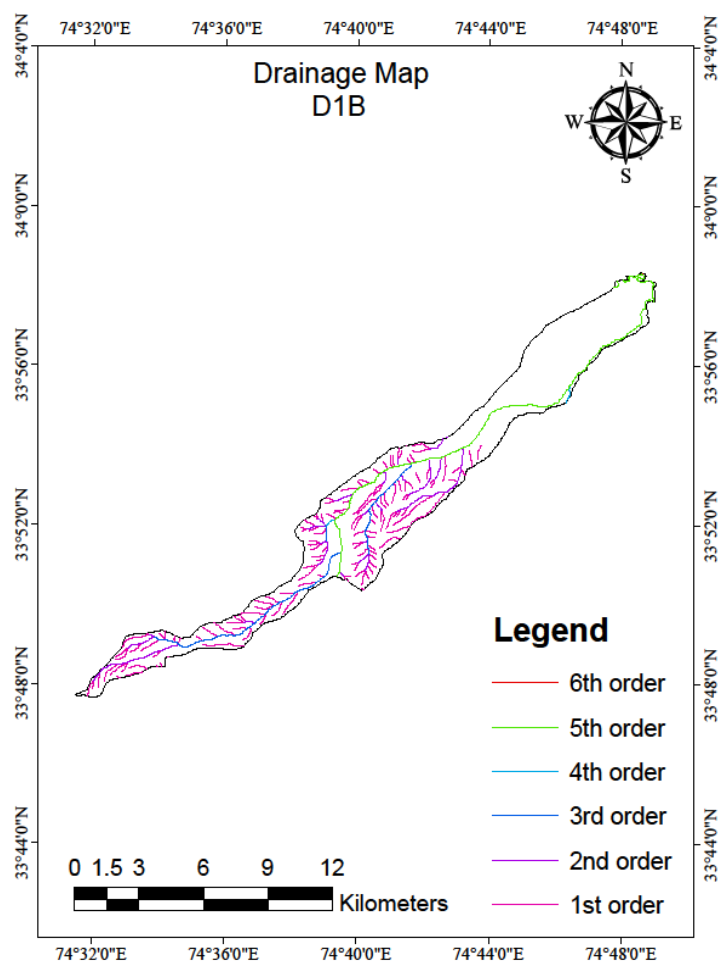

Figure 3: Drainage maps of watersheds of Dudhganga.

order. The watershed D1A having $6^{\text {th }}$ order streams covering an area of $149 \mathrm{Km}^{2}$. The watersheds D1B, D1C, D2A and D2B having $5^{\text {th }}$ order streams covering an area of $69 \mathrm{~km}^{2}, 88 \mathrm{~km}^{2}, 111 \mathrm{Km}^{2}$ and 243 . $\mathrm{Km}^{2}$ respectively. The highest number of stream segments is found in watershed D2A (350 stream segments) followed by watershed D1C (301 stream segments) while the lowest number of stream segments is found in watershed D2B (81). In whole Dudhganga catchment the first order

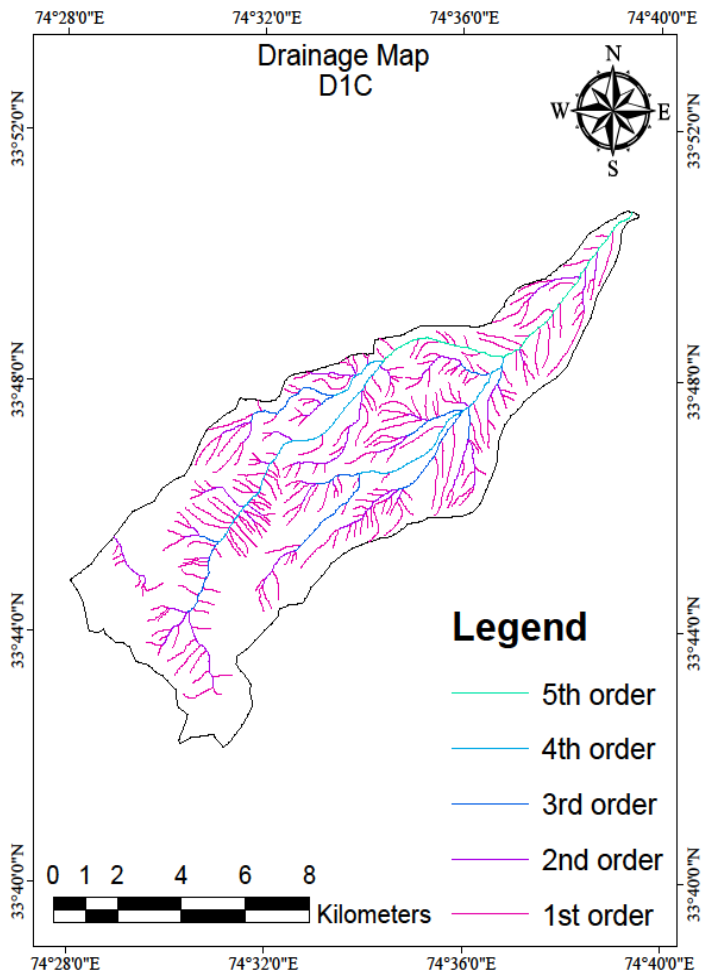

Figure 4: Drainage maps of watersheds of Dudhganga.

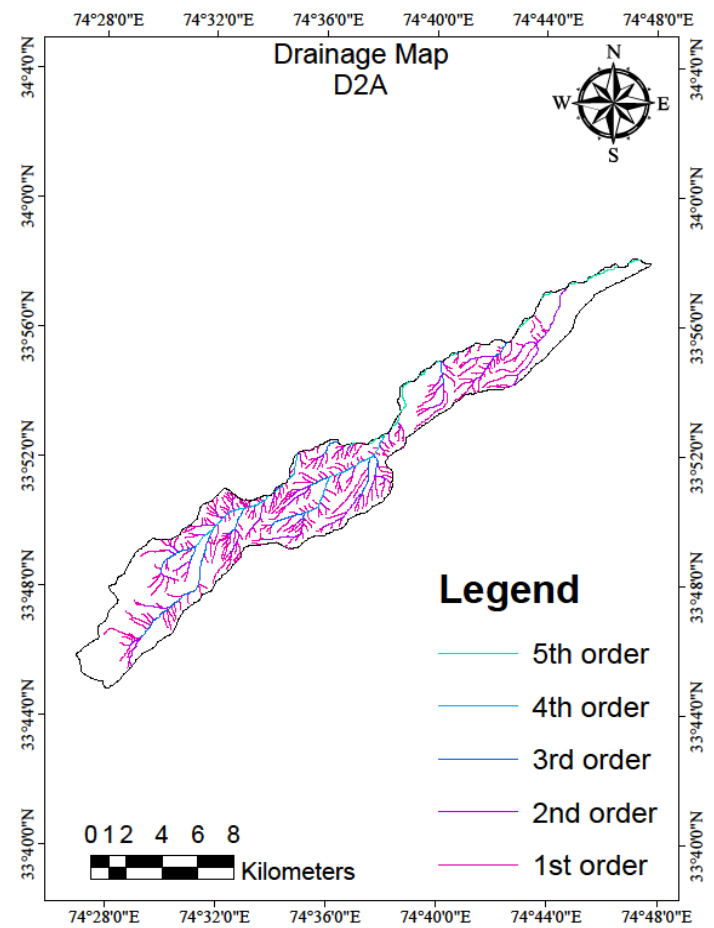

Figure 5: Drainage maps of watersheds of Dudhganga 


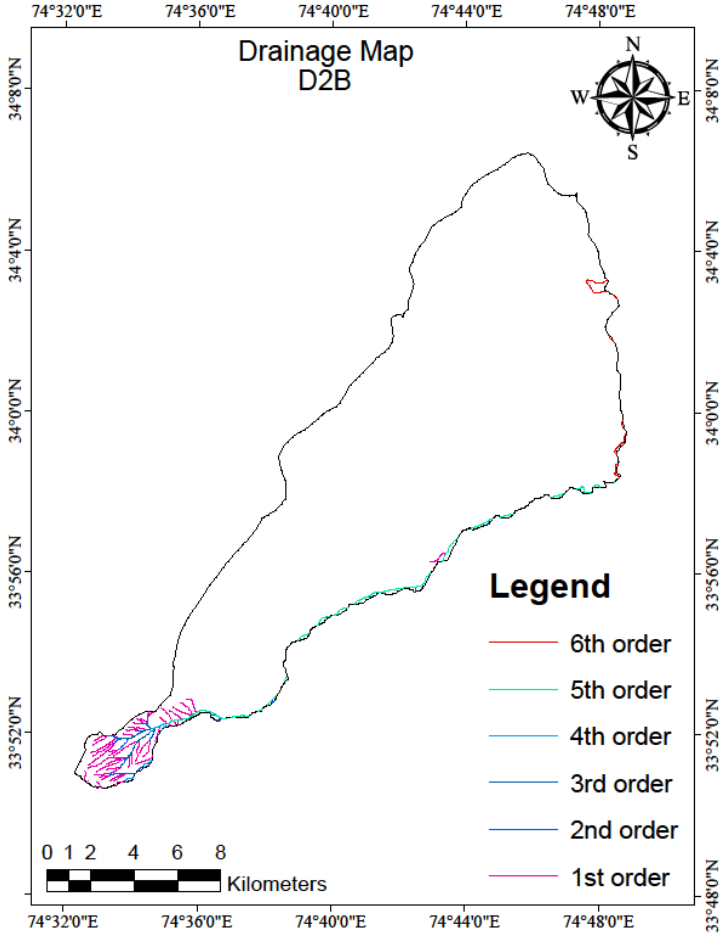

Figure 6: Drainage maps of watersheds of Dudhganga.

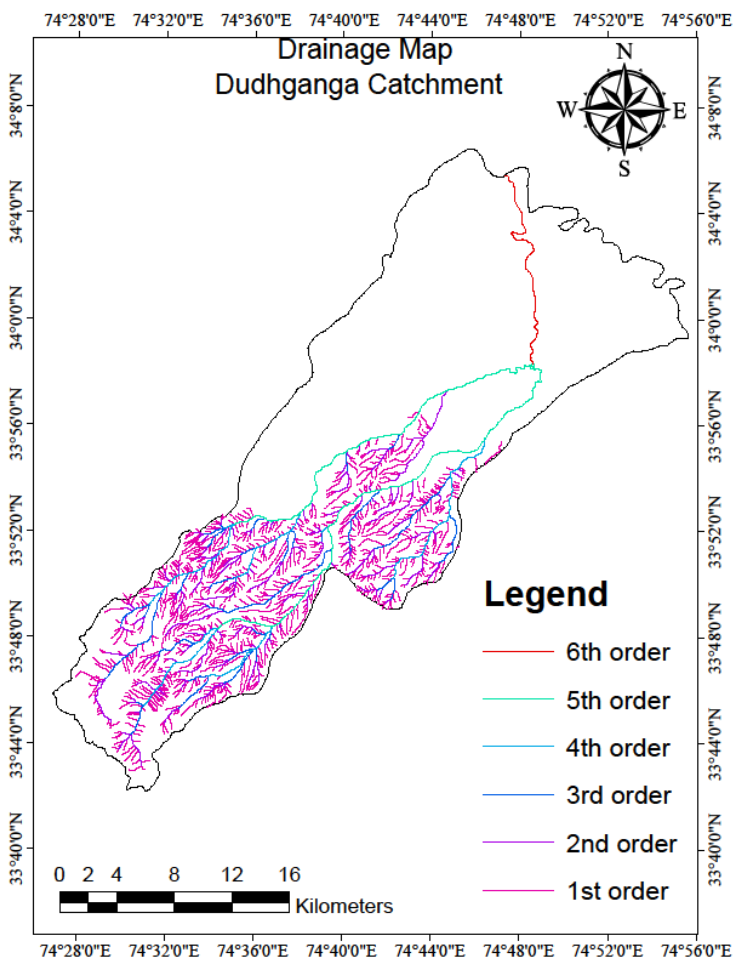

Figure 7: Drainage maps of watersheds of Dudhganga.

streams constitute 80.63 per cent while second order streams constitute 14.89 per cent of the total number of streams. Third and fourth order streams constitute 3.44 per cent and 0.74 per cent of the total number of streams respectively while fifth and sixth order streams constitute only 0.18 per cent and 0.09 per cent respectively of the total number of streams. Thus the law of lower the order higher the number of streams is implied throughout the catchment. It is observed that thevariation in order and size of the watersheds is largely due to physiographic, structural conditions of the region and infiltration capacity of the soil (Figures 2-7).

Stream length $(\mathbf{L u})$ : The stream length was computed on the basis of the law proposed by Horton [5], for all the five watersheds. Generally, the total length of stream segments decrease as the stream order increase. In 2 watersheds $\mathrm{D} 1 \mathrm{C}$ and $\mathrm{D} 2 \mathrm{~A}$ the stream length followed Horton's law. But in 3 watersheds D1A, D1B and D2B, the stream segments of various orders showed variation from general observation. It is evident in the (Table 3) that in Dudhganga catchment the length of first order streams constitute 60.60 per cent of the total stream length with second order (16.18 per cent), third order (8.82 per cent), fourth order (5.30 per cent), fifth order ( 7.12 per cent) and the sixth order (1.95 per cent). The total length of $1^{\text {st }}$ and $2^{\text {nd }}$ order streams constitutes 76.78 percent of the total stream length. It can be inferred that the total length of stream segments is maximum in first order streams and decreases as the stream order increases. However fifth order is an exception where the total stream length $(62.14 \mathrm{kms})$ is more than that of the fourth order $(46.03 \mathrm{kms})$. This change may indicate flowing of streams from high altitude, lithological variations and moderately steep slopes $[18,19]$.

Bifurcation ratios $(\mathbf{R b})$ : Horton [5] considered $\mathrm{Rb}$ as an index of reliefs and dissections. Strahler [10] demonstrated that Rb shows only a small variation for different regions with different environments except where powerful geological control dominates. Lower $\mathrm{Rb}$ values are the characteristics of structurally less disturbed watersheds without any distortion in drainage pattern [20]. Bifurcation ratio is related to the branching pattern of a drainage network and is defined as the ratio between the total number of stream segments of one order to that of the next higher order in a drainage basin [21]. The mean bifurcation ratio values of different watersheds of Dudhganga catchment (Table 5) shown variation from 2.79 to 5.65 indicates less structural control on the drainage development.

Stream frequency (Fs): Stream frequency is the total number of stream segments of all orders per unit area [22]. Fs valves indicate positive correlation with the Dd of all five watersheds of Dudhganga catchment. The stream frequencies of all the watersheds are mentioned in Table 4. The study revealed that the D1C and D2A watersheds have high stream frequency because of the fact that it falls in the zone of fluvial channels and the presence of ridges on both sides of the valley which results in highest Fs. The watersheds D1A and D1B have medium stream frequency and watershed D2B has poor stream frequency because of low relief.

Drainage density (Dd): It indicates the closeness of spacing between channels and is a measure of the total length of the stream segment of all orders per unit area. Drainage density in all the watersheds varies from 0.25 to 2.77 respectively (Table 5). In general it has been observed over a wide range of geologic and climatic types, that low drainage density is more likely to occur in regions of highly permeable subsoil material under dense vegetative cover, and where relief is low. In contrast, high Dd is favored in regions of weak or impermeable subsurface materials, sparse vegetation and mountainous relief [20]. Hence in this study high drainage density was found in D1C and D2A because of weak and impermeable sub surface material and mountainous relief. Figure 8 shows the drainage density of Dudhganga catchment. Low Dd value for watershed D1A and D1B indicates that it 
Citation: Iqbal M, Sajjad H (2014) Watershed Prioritization using Morphometric and Land Use/Land Cover Parameters of Dudhganga Catchment Kashmir Valley India using Spatial Technology. J Geophys Remote Sensing 3: 115. doi:10.4172/2169-0049.1000115
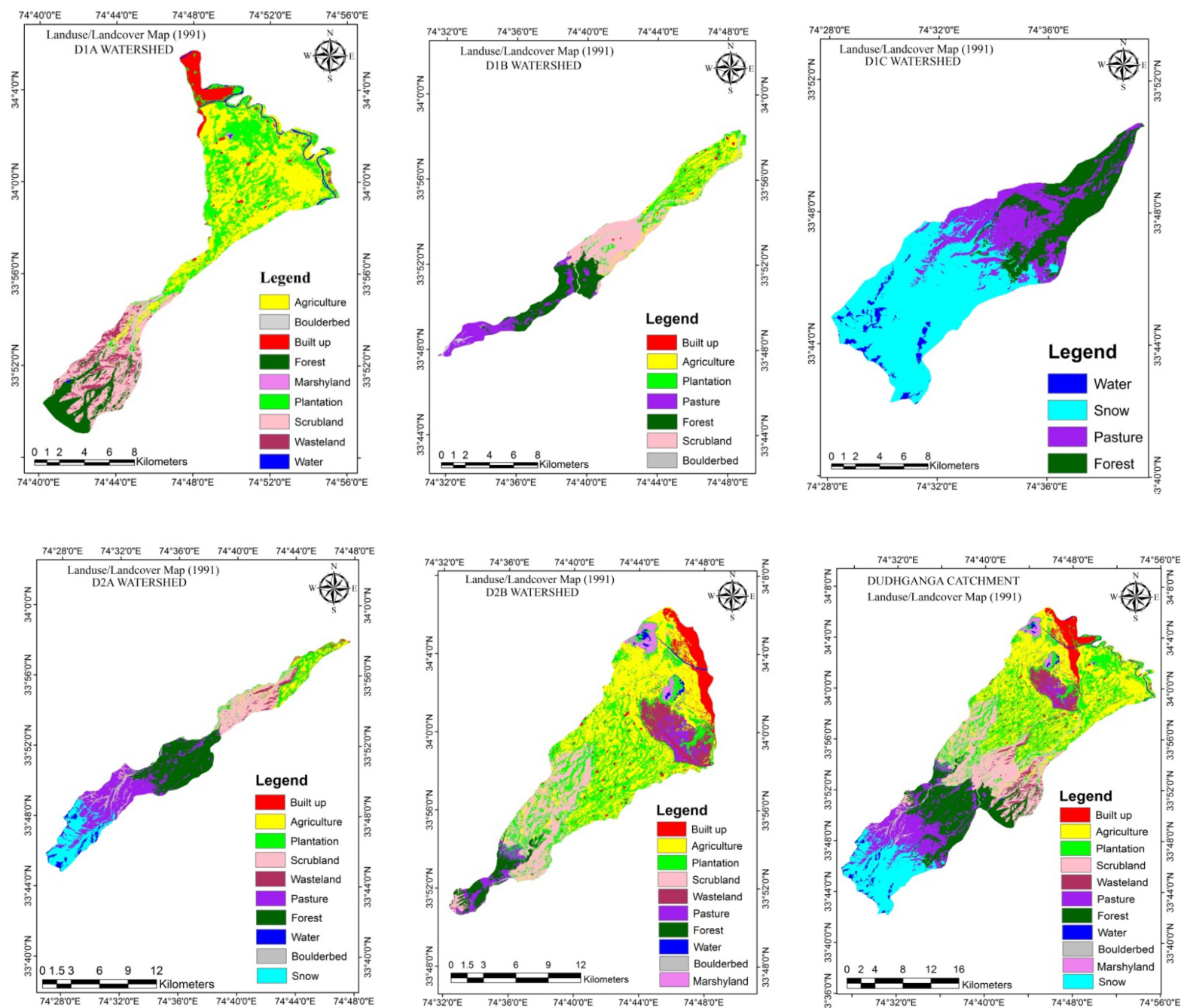

Figure 8: Land use/land cover maps (1991) of watersheds of Dudhganga catchment.

\begin{tabular}{|c|c|c|c|c|c|c|c|}
\hline Watersheds & $\begin{array}{l}\text { Area } \\
\left(\mathbf{k m}^{2}\right)\end{array}$ & $\begin{array}{l}\text { Stream Frequency } \\
\left(\mathbf{k m} / \mathbf{k m}^{2}\right)\end{array}$ & $\begin{array}{l}\text { Basin Length } \\
(\mathbf{k m})\end{array}$ & $\begin{array}{l}\text { Form } \\
\text { Factor }\end{array}$ & $\begin{array}{c}\text { Elongation } \\
\text { Ratio }\end{array}$ & $\begin{array}{l}\text { Circularity } \\
\text { Ratio }\end{array}$ & $\begin{array}{c}\text { Compactness } \\
\text { constant }\end{array}$ \\
\hline D1A & 149 & 1.21 & 36.60 & 0.11 & 0.37 & 0.17 & 0.39 \\
\hline D1B & 69 & 2.39 & 35.94 & 0.05 & 0.26 & 0.15 & 0.62 \\
\hline D1C & 88 & 3.42 & 23.15 & 0.16 & 0.46 & 0.38 & 0.34 \\
\hline D2A & 111 & 3.15 & 42.65 & 0.06 & 0.28 & 0.16 & 0.47 \\
\hline D2B & 243 & 0.33 & 32.55 & 0.23 & 0.54 & 0.36 & 0.21 \\
\hline Dudhganga Catchment & 660 & 1.63 & 62.56 & 0.17 & 0.46 & 0.33 & 0.13 \\
\hline
\end{tabular}

Table 4: Morphometric parameters of Dudhganga catchment.

\begin{tabular}{|c|c|c|c|c|c|c|c|c|c|}
\hline \multirow[t]{2}{*}{ Watersheds } & \multirow[t]{2}{*}{ Perimeter $\left(\mathbf{k m}^{2}\right)$} & \multirow{2}{*}{$\begin{array}{l}\text { Drainage } \\
\text { Density }\end{array}$} & \multirow{2}{*}{$\begin{array}{l}\text { Drainage } \\
\text { Texture }\end{array}$} & \multicolumn{5}{|c|}{ Bifurcation Ratios } & \multirow[t]{2}{*}{ Mean Rb } \\
\hline & & & & Rb1 & Rb2 & Rb3 & Rb4 & Rb5 & \\
\hline D1A & 103.37 & 1.00 & 1.75 & 8.21 & 4.75 & 4 & - & - & 5.65 \\
\hline D1B & 75.73 & 2.14 & 2.17 & 5.58 & 6 & 2 & 2 & - & 3.89 \\
\hline D1C & 53.86 & 2.77 & 5.58 & 5.5 & 4 & 3.66 & 3 & - & 4.04 \\
\hline D2A & 92.35 & 2.43 & 3.79 & 4.87 & 4.75 & 6 & 2 & - & 4.40 \\
\hline D2B & 91.53 & 0.25 & 0.88 & 3.5 & 2.66 & 3 & 2 & - & 2.79 \\
\hline Bifurcation Ratios & 157.51 & 1.32 & 6.81 & 5.41 & 4.32 & 4.62 & 4 & 2 & 4.07 \\
\hline
\end{tabular}

Table 5: Values of drainage density, texture and bifurcation ratios for Dudhganga catchment.

has highly permeable sub surface material and low relief. While as poor Dd is found in D2B watershed. It has been observed that low drainage density leads to coarse drainage texture while high drainage density leads to fine drainage texture. 
Citation: Iqbal M, Sajjad H (2014) Watershed Prioritization using Morphometric and Land Use/Land Cover Parameters of Dudhganga Catchment Kashmir Valley India using Spatial Technology. J Geophys Remote Sensing 3: 115. doi:10.4172/2169-0049.1000115
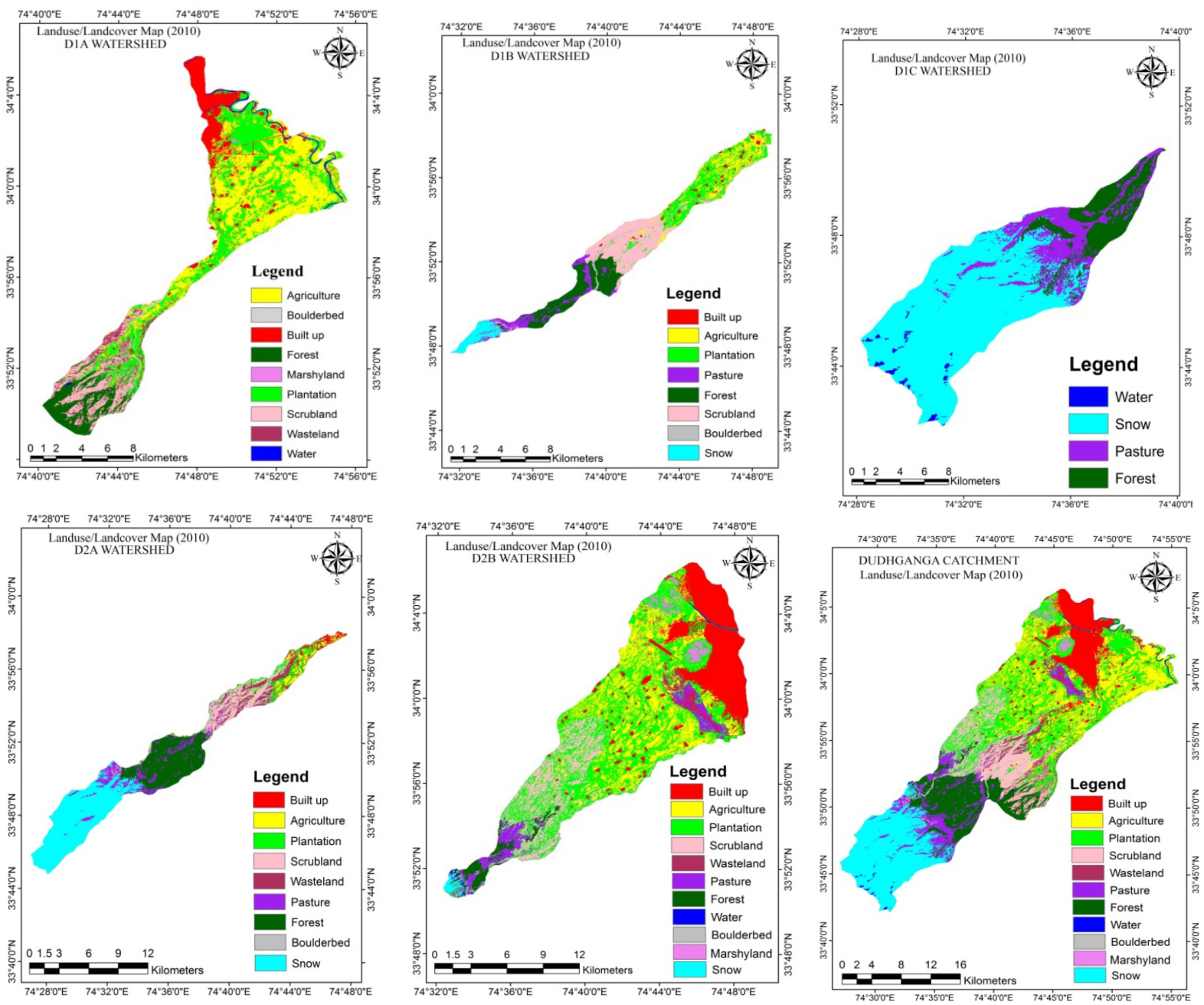

Figure 9: Land use/land cover maps (2010) of watersheds of Dudhganga catchment.

\begin{tabular}{|c|c|c|c|c|c|}
\hline Classes & 1991 (Area in Hectares) & Percentage & 2010 (Area in Hectares) & Percentage & Change Detection in (Hectares) \\
\hline Wasteland & 679.45 & 4.56 & 650.77 & 4.37 & -28.68 \\
\hline Scrub land & 2304.7 & 15.47 & 1677.1 & 11.26 & -627.6 \\
\hline Built up & 790.16 & 5.30 & 1812.2 & 12.16 & 1022.1 \\
\hline Marshy land & 14.458 & 0.09 & 9.016 & 0.06 & -5.442 \\
\hline Water bodies & 250.34 & 1.68 & 221.42 & 1.48 & -28.92 \\
\hline Plantation & 3681.1 & 24.71 & 5300.1 & 35.57 & 1619 \\
\hline Agriculture & 5821.4 & 39.07 & 4198.7 & 28.18 & -1622.7 \\
\hline Boulder bed & 68.148 & 0.46 & 45.405 & 0.30 & -22.74 \\
\hline Forest & 1290.3 & 8.66 & 985.26 & 6.62 & -305 \\
\hline Total & 14900 & 100 & 14900 & 100 & 2641.1 \\
\hline
\end{tabular}

Source: Author's estimation

Table 6: Land use/Land cover change in D1A watershed (1991-2010).

Drainage texture (Dt): The drainage texture depends upon a number of natural factors such as climate, rainfall, vegetation, rock and soil type, infiltration capacity, relief and stage of development [23]. The soft or weak rocks unprotected by vegetation produce a fine texture, whereas massive and resistant rocks cause coarse texture. Sparse vegetation of arid climate causes finer textures than those developed on similar rocks in a humid climate. Drainage texture is defined as the total number of stream segments of all orders per perimeter of the area (Horton). Smith [23] classified drainage into five classes i.e., very coarse
$(<2)$, coarse (2-4), moderate (4-6), fine (6-8) and very fine ( $>8)$. Horton [5] recognized infiltration capacity as the single important factor which influences drainage texture and considered drainage texture which includes drainage density and stream frequency. The drainage density values of watersheds range from 0.25 to 2.77 indicating very coarse to coarse drainage texture for Dudhganga catchment.

\section{Areal aspects of the drainage basin}

Form factor (Ff): Form factor is defined as the ratio of basin area 
Citation: Iqbal M, Sajjad H (2014) Watershed Prioritization using Morphometric and Land Use/Land Cover Parameters of Dudhganga Catchment Kashmir Valley India using Spatial Technology. J Geophys Remote Sensing 3: 115. doi:10.4172/2169-0049.1000115

Page 8 of 12

to the square of the basin length [22]. The values of form factor would always be less than 0.7854 (perfectly for a circular basin). Smaller the value of (Ff) more elongated will be the basin. The form factor for all watersheds varies from $0.05-0.16$, But the whole Dudhganga catchment have $0.17 \mathrm{Ff}$ (Table 4). The observation shows that the D1B and D2A watersheds are highly elongated while as the watersheds D1C and D2B are less elongated. The values of Ff for Dudhganga catchment indicates that the whole catchment is elongated. The elongated watershed with low value of $\mathrm{Ff}$ indicates that the basin will have a flatter peak flow for longer duration. Flood flows of such elongated basins are easier to manage than from the circular basin.

Elongation ratio (Re): Schumn [21] defined elongation ratio as the ratio between the diameter of the circle of the same area as the drainage basin and the maximum length of the basin. Analysis of elongation ratio indicates that the areas with higher elongation ratio values have high infiltration capacity and low runoff. A circular basin is more efficient in the discharge of runoff than an elongated basin [18]. The values of elongation ratio generally vary from 0.6 to 1.0 over a wide variety of climate and geologic types. Values close to 1.0 are typical of regions of very low relief, whereas values in the range 0.6 to 0.8 are usually associated with high relief and steep ground slope [9]. These values can be grouped in to three categories namely (a) circular $(>0.9)$, (b) oval $(0.9$ to 0.80 , (c) less elongated $(<0.7)$. The values of Re varies from 0.26 to 0.46 indicates that the catchment falls in the less elongated category.

Circularity ratio (Rc): Circularity ratio is the ratio of the area of the basin to the area of a circle having the same circumference as the perimeter of the basin [24]. It is influenced by the length and frequency of streams, geological structures, land use/ land cover, climate, relief and slope of the watershed. In the present study (Table 4), the Rc values for all watersheds vary from 0.15 to 0.38 which shows that the watersheds are almost elongated. This anomaly is due to diversity of slope, relief and structural conditions prevailing in these watersheds.

Compactness coefficient $(\mathrm{Cc})$ : Compactness coefficient is used to express the relationship of a hydrologic basin with that of a circular basin having the same area as the hydrologic basin. A circular basin is the most hazardous from a drainage stand point because it will yield the shortest time of concentration before peak flow occurs in the basin. The values of $\mathrm{Cc}$ in the five watersheds of Dudhganga catchment vary from 0.21 to 0.62 showing variations across the watersheds. But the overall value of Cc of Dudhganga catchment is 0.13 which is lesser than all five watersheds.

\section{Land use/land cover analysis}

There are few landscapes remaining on the earth's surface that have not been significantly altered or are not being altered by humans in some manner. Mankind's presence on the earth and his modification of the landscape has had a profound effect upon the natural environment. These anthropogenic influences on changing patterns of land use are a primary component of many current environmental concerns as land use and land cover change is gaining recognition as a key driver of environmental change [25]. The classified images have categorized into built up, agriculture, forest, boulder bed, plantation, pasture, scrub land, wasteland, marshy land, snow and water bodies. The Figures 8 and 9 present land use/land cover mapsof the catchment. The Dudhganga catchment as a whole presents a grim scenario as the land use/cover changes from 1991 to 2010 period indicate degradation of land and other natural resources. It was found that cultivated land decreased by 2.08 per cent per year, where as built up land increased by 9.06 per cent per year during the same period. Moreover, decrease in the forest cover 1.05 per cent per year and scrubland 1.20 per cent has been observed. However, 1.17 per cent per year reduction has observed in the wasteland area. The details of land use/land cover and the changes in area under each category in hectares as well as in percentage for each watershed from 1991 to 2010 period are presented in Tables 6-11. Since the Dudhganga catchment have five watersheds having agriculture as a primel and use activity supporting the livelihood of the local people, an increase in cultivated land, plantation and forest area can be considered as a positive change, as this is likely to bring environmental, economic and social benefits. Similarly, decrease in wasteland and scrubland is also regarded as a positive change as it will indicate reclamation and rehabilitation of degraded and unproductive land. In contrast, decrease in are a under forest, cultivated land, marshy land can be

\begin{tabular}{|c|c|c|c|c|c|}
\hline Classes & 1991 (Area in Hectares) & Percentage & 2010 (Area in Hectares) & Percentage & Change Detection in (Hectares) \\
\hline Pasture & 945.95 & 13.71 & 720.3 & 10.44 & -225.6 \\
\hline Boulder bed & 295.5 & 4.29 & 156.85 & 2.27 & -138.7 \\
\hline Scrubland & 1798.6 & 26.06 & 1702.6 & 24.67 & -96.01 \\
\hline Agriculture & 1277.4 & 18.51 & 767.98 & 11.13 & -509.4 \\
\hline Built up & 147.68 & 2.15 & 338.89 & 4.92 & 191.2 \\
\hline Plantation & 1029 & 14.91 & 1611.6 & 23.36 & 582.63 \\
\hline Forest & 1405.8 & 20.37 & 1189.8 & 17.24 & -216.1 \\
\hline Snow & 0 & 0 & 411.97 & 5.97 & 411.97 \\
\hline Total & 6900 & 100 & 6900 & 100 & 1185.8 \\
\hline
\end{tabular}

Source: Author's estimation

Table 7: Land use/Land cover change in D1B watershed (1991-2010).

\begin{tabular}{|c|c|c|c|c|c|}
\hline Classes & 1991 (Area in Hectares) & Percentage & 2010 (Area in Hectares) & Percentage & Change Detection in (Hectares) \\
\hline Pasture & 2046 & 23.25 & 1510.84 & 17.17 & -535.2 \\
\hline Forest & 1742 & 19.79 & 1179.72 & -562.4 \\
\hline Water & 249 & 2.83 & 115 & 13.39 \\
\hline Snow & 4763 & 54.13 & 5994.44 & 68.11 \\
\hline Total & 8800 & 100 & 8800 & 134 \\
\hline Plantation & 1029 & 14.91 & 1611.6 & 1231 & 100 \\
\hline
\end{tabular}

Source: Author's estimation

Table 8: Land use/Land cover change in D1C watershed (1991-2010). 
Citation: Iqbal M, Sajjad H (2014) Watershed Prioritization using Morphometric and Land Use/Land Cover Parameters of Dudhganga Catchment Kashmir Valley India using Spatial Technology. J Geophys Remote Sensing 3: 115. doi:10.4172/2169-0049.1000115

Page 9 of 12

\begin{tabular}{|c|c|c|c|c|c|}
\hline Classes & 1991 (Area in Hectares) & Percentage & 2010 (Area in Hectares) & Percentage & Change Detection in (Hectares) \\
\hline Built up & 215.72 & 1.94 & 458.5 & 4.13 & 242.78 \\
\hline Agriculture & 610.57 & 5.50 & 383.46 & 3.45 & -227.11 \\
\hline Forest & 2679.2 & 24.14 & 2400.2 & 21.62 & -279 \\
\hline Boulder bed & 339.68 & 3.07 & 145.88 & 1.33 & -193.8 \\
\hline Plantation & 787.31 & 7.09 & 763.68 & 6.88 & -23.63 \\
\hline Pasture & 2743.2 & 24.71 & 1095.3 & 9.87 & -1647.9 \\
\hline Scrub land & 1624.7 & 14.64 & 1205.2 & 10.86 & -419.5 \\
\hline Wasteland & 261.95 & 2.36 & 685.21 & 6.17 & 423.26 \\
\hline Snow & 1562.4 & 14.07 & 3962.5 & 35.69 & 2400.1 \\
\hline Water & 275.27 & 2.48 & 0 & 0 & -275.27 \\
\hline Total & 11100 & 100 & 11100 & 100 & 3066.2 \\
\hline
\end{tabular}

Source: Author's estimation

Table 9: Land use/Land cover change in D2A watershed (1991-2010).

\begin{tabular}{|c|c|c|c|c|c|}
\hline Classes & 1991 (Area in Hectares) & Percentage & 2010 (Area in Hectares) & Percentage & Change Detection in (Hectares) \\
\hline Built up & 1502.7 & 6.18 & 4860.7 & 20.00 & 3358 \\
\hline Agriculture & 8982.6 & 36.96 & 4380.2 & 18.02 & -4602 \\
\hline Forest & 854.65 & 3.52 & 540.88 & 2.23 & -313.8 \\
\hline Scrubland & 3267.3 & 13.45 & 2239.6 & 9.22 & -1028 \\
\hline Plantation & 5818.8 & 23.95 & 9778 & 40.24 & 3959.2 \\
\hline Pasture & 1162.9 & 4.78 & 1135.9 & 4.67 & -26.97 \\
\hline Boulder bed & 203.06 & 0.84 & 204.04 & 0.84 & 0.9747 \\
\hline Water & 199.73 & 0.82 & 33.059 & 0.14 & -166.7 \\
\hline Wasteland & 1615 & 6.65 & 616.66 & 2.54 & -998.3 \\
\hline Marshy land & 693.34 & 2.85 & 373.96 & 1.54 & -319.4 \\
\hline Snow & 0 & 0 & 136.95 & 0.56 & 136.95 \\
\hline Total & 24300 & 100 & 24300 & 100 & 7455.2 \\
\hline
\end{tabular}

Source: Author's estimation

Table 10: Land use/Land cover change in D2B watershed (1991-2010).

\begin{tabular}{|c|c|c|c|c|c|}
\hline Classes & 1991 (Area in Hectares) & Percentage & 2010 (Area in Hectares) & Percentage & Change Detection in (Hectares) \\
\hline Built up & 2656 & 4.02 & 7470 & 11.32 & 4814 \\
\hline Agriculture & 16692 & 25.29 & 9730 & 14.74 & -6962 \\
\hline Forest & 7972 & 12.08 & 6296 & 9.54 & -1676 \\
\hline Boulder bed & 906.4 & 1.36 & 552.2 & 0.84 & -354.2 \\
\hline Plantation & 11316 & 17.15 & 17453 & 26.44 & 6137 \\
\hline Pasture & 6898 & 10.45 & 4463 & 6.76 & -2436 \\
\hline Scrubland & 8995 & 13.63 & 6825 & 10.34 & -2171 \\
\hline Wasteland & 2556 & 3.87 & 1953 & 2.96 & -603.7 \\
\hline Snow & 6324 & 9.58 & 10505 & 15.91 & 4181 \\
\hline Water & 975 & 1.47 & 370 & 0.56 & -605 \\
\hline Marshy land & 707.8 & 1.1 & 383 & 0.58 & -324.8 \\
\hline Total & 66000 & 100 & 66000 & 100 & 15132 \\
\hline
\end{tabular}

Source: Author's estimation

Table 11: Land use/Land cover change in Dudhganga catchment (1991-2010).

taken as a negative change, indicating anthropogenic pressures and lack of conservation measures, similarly increase in the wasteland and pastureland is also regarded as a negative change. A general decrease in cultivated land area and increase in area built up area is common a cross all the five watersheds indicating negative change. There is also a general decline in forest areainD1a, D1b, D1c, D2a and D2b watersheds of the catchment. (Figures 8 and 9).

\section{Prioritization of watersheds}

Based on morphometric analysis: The morphometric parameters i.e., bifurcation ratio $(\mathrm{Rb})$, compactness coefficient $(\mathrm{Cc})$, drainage density (Dd), stream frequency (Fs), drainage texture (Dt), form factor $(\mathrm{Ff})$, circularity ratio $(\mathrm{Rc})$, and elongation ratio $(\mathrm{Re})$ are also termed as erosion risk assessment parameters and have been used for prioritizing watersheds [26]. The linear parameters such as drainage density, stream frequency, bifurcation ratio, drainage texture have a direct relationship with erodibility, higher the value, more is the erodibility. Hence for prioritization of watersheds, the highest value of linear parameters was rated as rank 1, second highest value was rated as rank 2 and so on, and the least value was rated last in rank. Shape parameters such as elongation ratio, compactness coefficient, circularity ratio, and form factor have an inverse relationship with erodibility [27], lower the value, more is the erodibility. Thus the lowest value of shape parameters was rated as rank 1 , next lower value was rated as rank 2 and so on and the highest value was rated last in rank. Hence, the ranking of the watersheds has been determined by assigning the highest priority/rank based on highest value in case of linear parameters and lowest value in case of shape parameters (Table 12). After the ranking has been done 
Citation: Iqbal M, Sajjad H (2014) Watershed Prioritization using Morphometric and Land Use/Land Cover Parameters of Dudhganga Catchment Kashmir Valley India using Spatial Technology. J Geophys Remote Sensing 3: 115. doi:10.4172/2169-0049.1000115

Page 10 of 12

\begin{tabular}{|c|c|c|c|c|c|c|}
\hline S. No. & Morphometric Parameters & D1A & D1B & D1C & D2A & D2B \\
\hline \multicolumn{7}{|c|}{ Linear parameters } \\
\hline 1 & Bifurcation Ratios (Rb) & $5.65(1)$ & $3.89(4)$ & $4.04(3)$ & $4.40(2)$ & $2.79(5)$ \\
\hline 2 & Drainage density (Dd) & $1(4)$ & $2.14(3)$ & $2.77(1)$ & $2.43(2)$ & $0.25(5)$ \\
\hline 3 & Drainage texture $(\mathrm{Dt})$ & $1.75(4)$ & $2.17(3)$ & $5.58(1)$ & $3.79(2)$ & $0.33(5)$ \\
\hline 4 & Stream frequency (Fs) & $1.21(4)$ & $2.39(3)$ & $3.42(1)$ & $3.15(2)$ & $0.33(5)$ \\
\hline \multicolumn{7}{|c|}{ Shape parameters } \\
\hline 5 & Circularity Ratio (Rc) & $0.17(3)$ & $0.15(1)$ & $0.38(5)$ & $0.16(2)$ & $0.36(4)$ \\
\hline 6 & Compactness coefficient (Cc) & $0.39(3)$ & $0.62(5)$ & $0.34(2)$ & $0.47(4)$ & $0.21(1)$ \\
\hline 7 & Form factor (Ff) & $0.11(3)$ & $0.05(1)$ & $0.16(4)$ & $0.06(2)$ & $0.23(5)$ \\
\hline 8 & Elongation Ratio (Re) & $0.37(3)$ & $0.26(1)$ & $0.46(4)$ & $0.28(2)$ & $0.54(5)$ \\
\hline \multicolumn{2}{|r|}{ Compound scores } & 3.13 & 2.63 & 2.63 & 2.25 & 4.38 \\
\hline & priority & Medium & High & High & High & Low \\
\hline \multicolumn{7}{|c|}{ Land use category and change in area (Hectares) } \\
\hline 9 & Wasteland & $-28(2)$ & - & - & $+423(1)$ & $-998(3)$ \\
\hline 10 & Scrubland & $-627(2)$ & $-96(4)$ & - & $-419(3)$ & $-1028(1)$ \\
\hline 11 & Built up & $1022(2)$ & $191(4)$ & - & $242(3)$ & $3358(1)$ \\
\hline 12 & Agriculture & $-1622(2)$ & $-509(3)$ & - & $-227(4)$ & $-4602(1)$ \\
\hline 13 & Marshy land & $-5.4(2)$ & - & - & - & $-319(1)$ \\
\hline 14 & Forest & $-305(3)$ & $-216(5)$ & $-562(1)$ & $-279(4)$ & $-313(2)$ \\
\hline 15 & Pasture & - & $-225(3)$ & $-535(2)$ & $-1647(1)$ & $-26(4)$ \\
\hline 16 & Plantation & $1619(3)$ & $582(2)$ & - & $-23(1)$ & $3939(4)$ \\
\hline \multicolumn{2}{|r|}{ Compound scores } & 2.28 & 3.5 & 1.5 & 2.43 & 2.12 \\
\hline \multicolumn{2}{|r|}{ priority } & Medium & Low & High & Medium & High \\
\hline \multicolumn{2}{|r|}{ Common priority } & Medium & - & High & - & - \\
\hline
\end{tabular}

Note: Values in parenthesis indicate priority/rank

Table 12: Priorities of watersheds and their ranks.
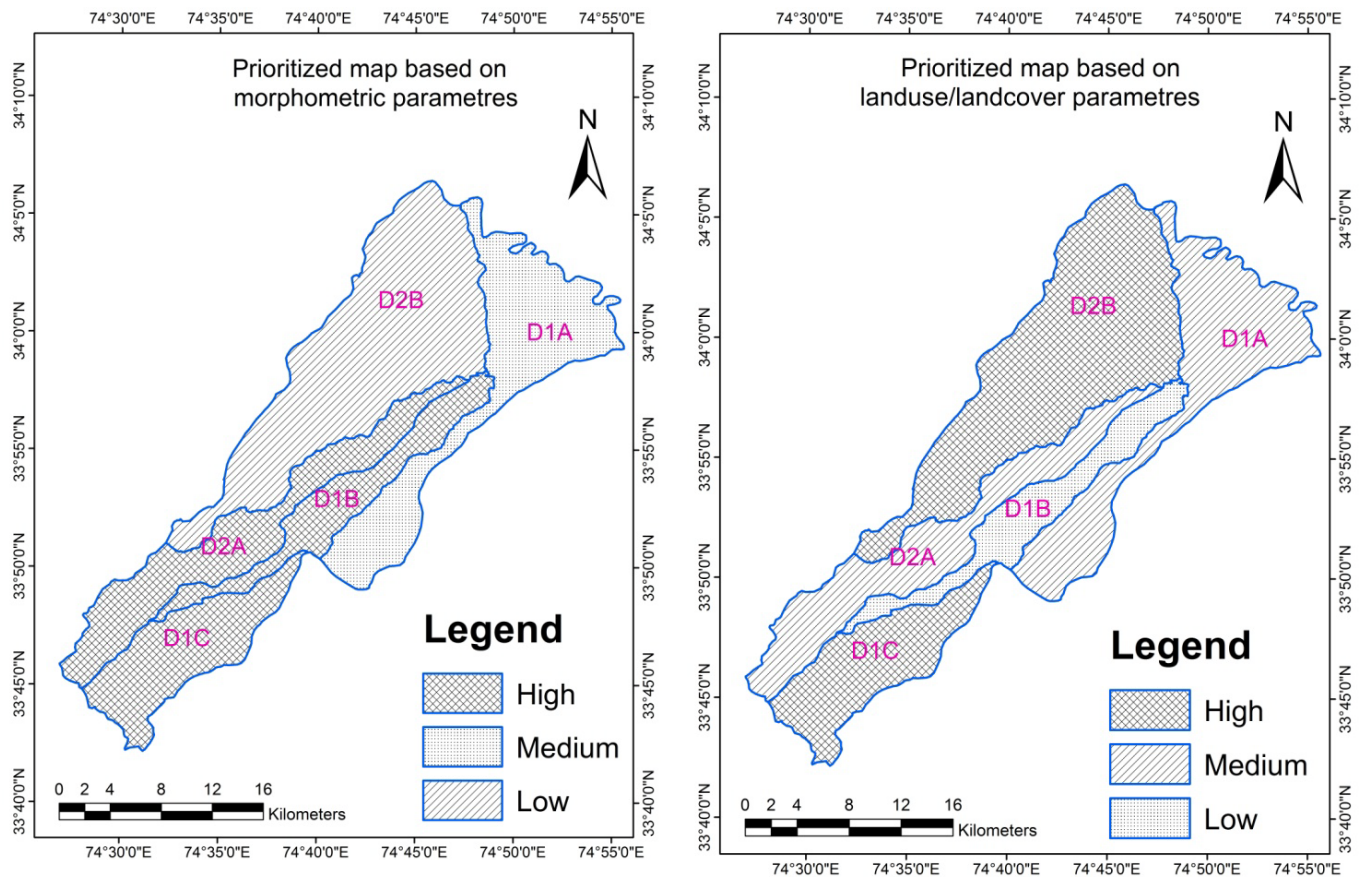

Figure 10: Priority of watersheds based on morphometric and land use/land cover analysis.

based on every single parameter, the ranking values for all the linear and shape parameters of each watershed were added up for each of the five watersheds to arrive at compound value $(\mathrm{Cp})$. Based on average value of these parameters, the watersheds having the least rating value was assigned highest priority, next higher value was assigned second priority and so on. The watershed which got the highest $\mathrm{Cp}$ value was assigned last priority. The watersheds were then categorized into three classes as high (<2.63), medium (2.64-3.13) and low (>3.13) priority on the basis of the range of $\mathrm{Cp}$ value. Hence, on the basis of morphometric analysis, D1B, D1C and D2A fall in the high priority, D1Afallin medium priority and D2B in the low priority category (Table 12).

Based on land use/land cover analysis: Common land use categories i.e., wasteland, cultivated land, built up, agricultural land, 


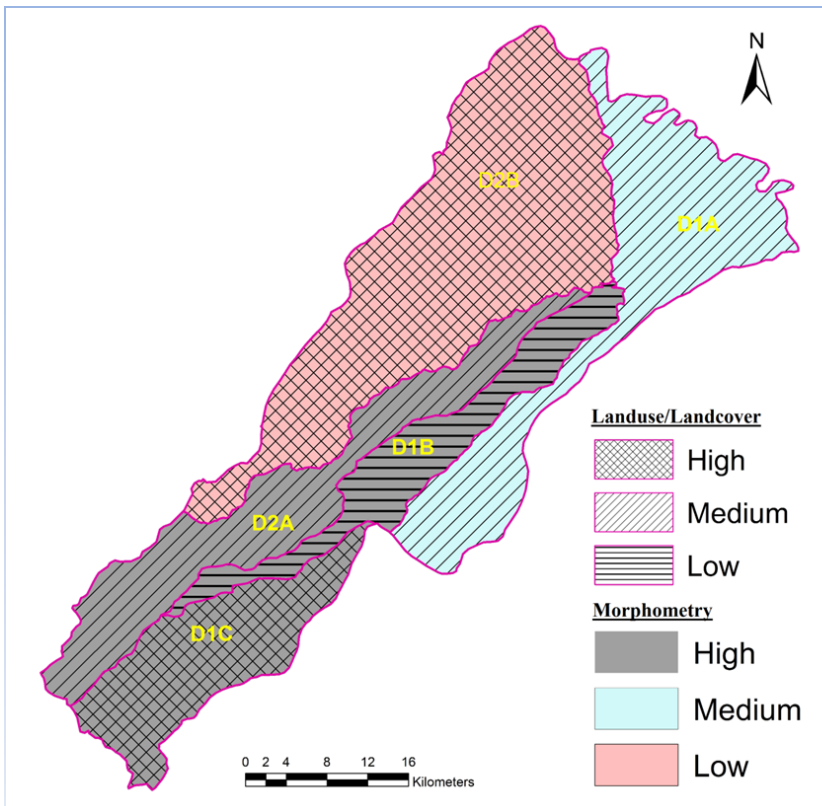

Figure 11: Priority of watersheds based on superimposition of morphometric and land use/land cover parameters.

pasture, forest, plantation, marshy land andscrubland in all the five watersheds were considered for prioritization of watersheds based on land use/land cover change analysis. The change in area (hectares) under each category of land use was ranked and assigned ranks (Table 12). All watersheds have reported negative change in respect of agricultural land, pasture, scrubland and forest cover, i.e., there has been overall decrease in agricultural land, pasture, scrubland and forest cover across all watersheds from 1991 to 2010 . However, wasteland shows some positive change, since the area under wasteland has reduced in two watersheds (D1A and D2B), besides there has been tremendous increase in area under plantation and built up are as in all waterheds.

For prioritization of watersheds the highest value (in hectares) under land use categories of built up, agricultural land, marshy land, forest cover pasture and scrubland were rated as rank 1 , second highest value as rank 2 and so on. However, highest ranking was given to the highest value among the land use category showing positive change, i.e., increase in plantation (Table 12). Finally, the ranking under each land use category was added up to arrive at compound value (Cp), lower the $\mathrm{Cp}$ value higher is the priority. The priority was given by classifying the highest and lowest range of $\mathrm{Cp}$ value into three classes as high $(<2.16)$, medium (2.16-2.82) and low (>2.82) priority. Hence, on the basis of land use change analysis D1C and D2B fall in the high priority, D1A and $\mathrm{D} 2 \mathrm{~A}$ fall in medium priority and D1B in the low priority category (Table12 and Figure 10).

The results obtained from morphometric and land use/land cover analysis have been correlated to find out the common watersheds falling under each priority. The correlation shows that D1C and D1A being the common watersheds which falls under high priority and medium priority respectively based on morphometric as well as land use/cover analysis. The other three watersheds exhibit little correlation and differ in their priority under morphometric and land use/land cover analysis (Table 12). Figure 11 shows correlation of watersheds based on integration of morphometric and land use/land cover parameters after both the themes are superimposed in GIS.

\section{Conclusion}

Watershed prioritization is considered as one of the most important aspects of planning and development for natural resources for water conservation measures. The present study recapitulates the integrated approach for developing a preliminary prioritization of watersheds in Dudhganga catchment. The result of prioritization on the basis of morphometric analysis revealed that D1B, D1C and D2A watersheds fall under very high priority, where as D1C and D2B also fall under very high priority on the basis of land use/land cover analysis. However, on the superimposition of the thematic layers of morphometric and land use/land cover in GIS environment, only two watersheds D1C and D1A being the common watersheds which fall under high priority and medium priority respectively, whereas the rest of watersheds show little or no correlation. The watersheds which are falling under very high priority may be taken up for implementation of soil and water conservation measures. The study demonstrates the utility of remote sensing and GIS techniques in prioritization of watersheds which may be helpful for planners and decision makers for planning at watershed level.

\section{References}

1. Agarwal CS (1998) Study of drainage pattern through aerial data in Naugarh area of Varanasi district, U.P. Jour Indian Soc Remote Sensing 26: 169-175.

2. Obi Reddy GE, Maji AK, Gajbhiye KS (2002) GIS for morphometric analysis of drainage basins. GIS India 4: 9-14.

3. Iqbal M, Sajjad H, Bhat FA (2012) Watershed level morphometric analysis of Dudhganga catchment, Kashmir Valley, India using geographical information system. Int J Current Res 4: 410-416.

4. Iqbal M, Sajiad H, Bhat FA (2013) Morphometric Analysis of Shaliganga Sub Catchment, Kashmir Valley, India Using Geographical Information System. Int J Eng Trends Technol 4: 10-21.

5. Horton RE (1945) Erosional development of streams and their drainage basins: Hydrophysical approach to quantitative morphology. Geol Soc Am Bull 56: 275370.

6. Leopold LB, Maddock T (1953) The hydraulic geometry of stream channels and some physiographic implications. United States Government Printing Office, Washington.

7. Abrahams AD (1984) Channel networks: a geomorphological perspective. Water Resour Res 20:161-168.

8. Singh S (2007) Geomorphology, Prayag Pustak Bhawan, Allahabad

9. Strahler AN (1964) Quantitative geomorphology of drainage basins and channe networks: Handbook of applied hydrology. McGraw Hill Book Company, New York, Section 4-76.

10. Strahler AN (1957) Quantitative analysis of watershed geomorphology. Trans Am Geophys Union 38: 913-920.

11. Krishnamurthy J, Srinivas G, Jayaram V, Chandrasekhar MG (1996) Influence of rock type and structure in the development of drainage networks in typical hard rock terrain. ITC J 4: 252-259.

12. Turner BL II, Clark C, Kates RW, Richards JF, Mathews JT, et al. (1990) The Earth as Transformed by Human Action: Global and Regional Changes in the Biosphere over the Past 300 Years. Cambridge University Press, Cambridge, UK.

13. Vittala SS, Govindaiah S, Honne GH (2008) Prioritization of sub-watersheds for sustainable development and management of natural resources: An integrated approach using remote sensing, GIS and socio-economic data. Current Sci 95: 345-354.

14. Moore ID, Grayson RB, Ladson AR (1991) Digital terrain modeling: A Review of Hydrological, Geomorphological and Biologial Application. Hydrol Process 5: 3-30.

15. Honore G (1999) Our Land, Ourselves—a Guide to Watershed Management in India. New Delhi, India. 
Citation: Iqbal M, Sajjad H (2014) Watershed Prioritization using Morphometric and Land Use/Land Cover Parameters of Dudhganga Catchment Kashmir Valley India using Spatial Technology. J Geophys Remote Sensing 3: 115. doi:10.4172/2169-0049.1000115

16. All India Soil and Land Use Survey (1990) Watershed Atlas of India on 1:1 Million Scale: Chief Soil Survey Officer, AIS \& LUS, Govt. of India, New Delhi, India.

17. Raza M, Ahmad A, Mohammad A (1978) The Valley of Kashmir: A Geographical Interpretation.

18. Singh S, Singh MC (1997) Morphometric analysis of Kanhar river basin National Geographical J of India 1: 31-43.

19. Vittala S, Govindaiah S, Honne GH (2004) Morphometric analysis of subwatersheds in the Pavagada area of Tumkur district, South India using remote sensing and GIS techniques. J Indian Soc Remote Sensing 4: 351-362.

20. Nag SK (1998) Morphometric analysis using remote sensing techniques in the Chaka sub-basin, Purulia district, West Bengal. J Indian Soc Remote Sensing 1: $69-76$

21. Schumn SA (1956) Evolution of drainage systems and slopes in badlands at Perth Amboy, New Jersey. Geol Soc Am Bull 67: 597-646.
22. Horton RE (1932) Drainage basin characteristics. Trans Am Geophysc Union 13: $350-361$

23. Smith KG (1950) Standards for grading textures of erosional topography. Am J Sci 248: 655-668.

24. Miller VC (1953) A quantitative geomorphic study of drainage basin characteristics in the clinch mountain area, Virgina and Tennessee. Columbia University, New York, USA.

25. Riebsame WE, Meyer WB, Turner II BL (1994) Modelling land use and cover as part of global environmental change. Climate Change 28: 45-64.

26. Biswas S, Sudhakar S, Desai VR (1999) Prioritization of sub-watersheds based on Morphometric Analysis of Drainage Basin, District Midnapore, West Bengal. J Indian Soc Remote Sensing 27: 155-166.

27. Ratnam NK, Srivastava YK, Rao VV, Amminedu E, Murthy KSR (2005) Check dam positioning by prioritization of micro-watersheds using SYI model and morphometric analysis- Remote Sensing and GIS perspective. J Indian Soc Remote Sensing 33: 25-38 